farmers, but this is a social and political problem not connected to forest sustainability.

\section{Geography Department,}

T. C. WHITMORE

\section{Downing Place,}

University of Cambridge,

Cambridge CB2 3EN, UK

\section{Concentrating mammalian urine}

SIR - Alexander in News and Views ${ }^{1}$ asserts that "The Australian hopping mouse (Notomys) conserves water . by producing more concentrated urine than any other mammal. . . To do this, it needs very long kidney tubules. ..". Actually, small rodents, including Notomys, concentrate urine with very short kidney tubules. In Notomys, the longest loops of Henle, the tubules responsible for concentrating urine, are only $5.2 \mathrm{~mm}$ long, and Notomys achieves a urine concentration of 9,370 mosmol. Horses, with loops 7 times as long, achieve maximum concentrations of only 1,900 mosmol. For all mammals, there is no trend for increased concentrating ability with increased loop of Henle length ${ }^{2}$. Birds decrease urine concentrating ability with increased loop length ${ }^{3}$.

Small mammals with short loops might produce concentrated urine because of the relationship between mass-specific metabolic rate and body size $e^{4,5}$. Small mammals (and their kidneys) have more intense metabolic rates than large mammals. The mitochondrial density in the loops of Henle in small mammals (such as mice) is about twice the density of large mammals (horses), and renal mitochondria in small mammals are more densely packed with cristae than in large mammals ${ }^{6}$. Tubule cells of small mammals also have higher densities of basolateral membrane infoldings (insertion sites for the ion pumps that contribute to concentrating urine). Thus, small mammals may produce high urine concentrations with short loops because, compared to larger mammals, the kidneys of small mammals may have a greater capacity for the active transport underlying the concentrating mechanism.

Alexander asks why other mammals do not match the concentrating ability of desert rodents, yet few desert rodents exceed the concentrating ability of the house mouse (Mus musculus), not a desert specialist ${ }^{7}$. Why large mammals do not have greater renal mitochondrial densities may be a matter of rules relating body size to metabolic rate. Given the scant evidence relating tubule length to concentrating ability, it is difficult to understand why any mammal has any particular loop length. In sum, long loops of Henle exist more in the minds of zoologists than in the kidneys of desert rodents.

Department of Zoology,

LEWIS GREENWALD

Ohio State University,

Columbus,

Ohio 43210-1293, USA

1. Alexander, R. MCN. Nature 353, 696 (1991).

2. Beuchat, C. A. Am. J. Physiol. 258, R298-R308 (1990)

3. Goldstein, D. L. \& Braun, E. J. Am. J. Physiol. 256, R501-R509 (1987).

4. Greenwald, L. Physiol. Zool. 62, 1005-1014 (1989)

5. Greenwald, L. \& Stetson, D. News Physiol. Sci. 3, 46-49 (1988).

6. Abrahams. S., Greenwald, L. \& Stetson, D. L. Am. J. Physiol. 261, R719-R726 (1991).

7. Haines, H., Ciskowski, C. \& Harms, V. Physiol. Zool. 46 110-128 (1973)

\section{Plants at the $K / T$ boundary}

SIR - I cannot accept the scheme presented by Jack A. Wolfe ${ }^{1}$ for a 'June impact' at the Cretaceous/Tertiary boundary. Not only has Wolfe extrapolated an elaborate sequence of events of global consequence from a single locality, but some of the critical evidence he cites is in my view invalid.

Wolfe reports two kinds of fossil pollen from the Teapot Dome locality that he interprets respectively as "Nupharlike pollen" (Fig. $3 e$ ) and "Nelumbo-like pollen" (Fig. 3l). On the basis of my inspection of Wolfe's slides, which he made available to me before publication of his letter, I believe that both kinds of pollen were misidentified. Specimens of alleged pond lily (Nymphaeacea) pollen (Wolfe's Fig 3e) are not "Nuphar-like" because they lack characteristic monosulcate apertures. They are Pandaniidites typicus (Norton) Sweet (synonym: $P$. radicus Leffingwell), a species having a monoporate aperture; this species has probable affinity with the Pandanaceae ${ }^{2}$. It is common in uppermost Cretaceous (Maastrichtian) as well as lower Tertiary (Palaeocene) rocks of the region ${ }^{3,4}$, hence its stratigraphic range exceeds that of the solely Palaeocene leaf species Paranymphaea crassifolia. Wolfe's argument that the co-occurrence of the leaves and pollen in his samples indicates derivation from the same plant is negated by the significant discordance in their total stratigraphical ranges.

Specimens of alleged lotus (Nelumbonaceae) pollen such as the tetrad illustrated by Wolfe (Fig. 3l) are not "Nelumbo-like" because they are tetrads (extant Nelumbo produces pollen as individual grains or monads of considerably larger size than the fossils) and because the fossils lack the tricolpate apertures and complexly structured walls (exines) characteristic of Nelumbo pollen. These fossils are Inaperturotetradites scabratus Tschudy, a species of uncertain botanical affinity but lacking any morphologic resemblance to pollen of Nelumbo. Wolfe's statement that "in extant Nelumbo, tetrads occur in young (immature) pollen" is irrelevant, because pollen of all species of seed plants originates as tetrads (as a consequence of meiosis during pollen genesis). Wolfe seems to have misinterpreted the caption to a drawing by Erdtman ${ }^{5}$ illustrating the relative positions of colpate apertures on adjacent daughter cells of a tetrad during development of the pollen. Erdtman's drawing clearly illustrates the welldeveloped tricolpate apertures and complex exine of Nelumbo pollen - features lacking in the inaperturate, thin-walled fossils in the Teapot Dome samples.

More significant than these misidentifications of the fossil pollen is the observation that fossil tetrads identical to those from Teapot Dome, which Wolfe regards as immature stages from plants suddenly frozen at the Cretaceous/Tertiary boundary, are widely known from Upper Cretaceous (Campanian and Maastrichtian) rocks in Wyoming and Montana ${ }^{6}$. Unless countless sudden freezing events throughout Late Cretaceous time are invoked to explain other occurrences of I. scabratus, the Teapot Dome specimens cannot be said to represent pollen frozen during the terminal Cretaceous event. Without immature "Nelumbo-like" pollen to indicate unopened flowers of fossil Nelumbites, the hypothesis that an impact happened in June at the end of Cretaceous time has no support.

Further, my counts of fossil pollen on Wolfe's slides revealed that the tetrads in question are most abundant in bed 2 and that the misidentified specimens said to represent pond lilies are most abundant in bed 4 . The law of superposition dictates that the tetrads were produced before the alleged lily pollen, the reverse of the sequence listed by Wolfe in his Table 1. Therefore, although Wolfe's analysis suggests the potential that exists for detailed analyses of the stratigraphic record at the Cretaceous/Tertiary boundary, his interpretation of the events that occured are not supported by the available data.

US Geological Survey,

DOUGLAS J. NiCHOLS

Mail Stop 919, Box 25046.

Denver, Colorado 80225, USA

SIR - Despite calling attention to the potential of microstratigraphic analysis to provide insights into geological events of extremely short duration, the letter by J. A. Wolfe ${ }^{1}$ contains numerous palaeobotanical and stratigraphic statements to which we object.

Although fresh leaves of Nuphar that we froze for more than 3 weeks dupli- 